\title{
Cyanobacteria and Glutathione Applications Improve Productivity, Nutrient Contents, and Antioxidant Systems of Salt-Stressed Soybean Plant
}

\author{
Safi-naz S. Zaki ${ }^{1}$, Eman E.E. Belal ${ }^{2 *}$, Mostafa M. Rady ${ }^{3}$ \\ ${ }^{1}$ Department of Water Relations and Field Irrigation, Agricultural and Biological Research Division, \\ National Research Centre, 33 El Behouth St., (Former El Tahrir St.) 12622 Dokki, Giza, Egypt. \\ ${ }^{2}$ Soil and Water Science Department, Faculty of Agriculture, Fayoum University, Fayoum 63514, \\ Egypt
}

${ }^{3}$ Botany Department, Faculty of Agriculture, Fayoum University, Fayoum 63514, Egypt

*dr_emanembaby@yahoo.com

Keywords: Soybean, Salt stress, Glutathione, Cyanobacteria, Antioxidant defense systems, Nutrients, Growth

\begin{abstract}
Salt stress restricts plant performance by disrupting various physio-biochemical processes like photosynthesis. Plants growing in saline substrates show deficiencies in absorption of some essential elements due to the presence of excessive sodium $\left(\mathrm{Na}^{+}\right)$in the rhizosphere, which antagonizes beneficial cations and causing toxicity in metabolism. Cyanobacteria (CB; a natural biofertilizer) play a fundamental role in building-up soil fertility, thus increasing plant performance. Glutathione (GSH) is a well-known antioxidant, which contributes to increase salt tolerance in the plant. This work was conducted as a pot experiment (sand culture) in 2017 to study the combined effect of CB, applied as seed inoculation, and GSH, applied as foliar spray, on growth, pods and seed yields, the contents of antioxidants, osmoprotectants, and nutrients, and the antioxidative enzymes activities of soybean (Glycine max L., cv. Giza 111) plants grown under saline conditions. At fourth leaf stage (21 days after sowing; DAS), CB-pretreated seedlings were supplemented with $\mathrm{NaCl}(150 \mathrm{mM})$ along with Hoagland's nutrient solution, and at the same time seedlings were sprayed with $1 \mathrm{mM}$ GSH. Samples were taken at 60 DAS to assess morphological, physiobiochemical and antioxidant defense systems attributes. Results showed that the integrative application of CB and GSH under saline conditions was effective in improving significantly the growth characteristics, yield components, photosynthetic efficiency (pigments contents and chlorophyll fluorescence), membrane stability index, relative water content, contents of soluble sugars, free proline, ascorbic acid, glutathione, $\alpha$-tocopherol, and protein, and activities of superoxide dismutase, catalase, and guaiacol peroxidase. The contents of macronutrients $\left(\mathrm{N}, \mathrm{P}, \mathrm{K}^{+}\right.$, and $\mathrm{Ca}^{2+}$ ) were also increased significantly in Glycine max plants compared to the stressed control. In contrast, $\mathrm{Na}^{+}$content and electrolyte leakage were significantly reduced. Our results recommend using the combined CB (as seed inoculation) and GSH (as foliar spray) application for soybean plants to grow well under saline conditions.
\end{abstract}

\section{Introduction}

Soybean is an important nutritional and medicinal crop. Its oil is classified as polyunsaturated, including approximately $24 \%$ monounsaturated and $61 \%$ polyunsaturated oil, besides $15 \%$ saturated oil. Approximately $53.2 \%$ from the polyunsaturated oil is linoleic acid, whereas linolenic acid comprises approximately $7.8 \%$. This gives advantages to regulate plasma lipid and eicosanoids biosynthesis based on the results obtained from many studies of human clinical trials. These clinical trials have reported that soybean oil effectively lower the serum cholesterol, and likely it can be used as a potential hypocholesterolemic agent if it used as a dietary fat and helps prevent atherosclerosis and heart diseases [1].

Under salinity stress, decrease in plant growth is interlinked, usually, with a diverse group of physio-biochemical and molecular characteristics [2,3]. Plant response to salt stress is very complex and varies from species to species and even from cultivar to cultivar within the same 
species [4, 5]. Most plants exposed to saline regimes show alterations in different physiobiochemical attributes and antioxidant defense (non-enzymatic and enzymatic systems [6-9]. The most common phyio-biochemical attributes affected by salinity stress in different plants include protein synthesis and phytohormone regulation [10], photosynthetic capacity [9, 11], water relations [12], and activity of enzymatic antioxidants and level of inorganic nutrients [7-9, 12, 13]. Under salt stress, reactive species of oxygen (ROS) are overproduced in plants in response to stress conditions as one of the key secondary effects of salinity stress on plants $[13,14]$. These ROS cause damage to cellular ultrastructure and organic compound as well as impair a variety of metabolic process reactions $[14,15]$. Under salt stress, plants show more negative water potential that negatively affects plant growth [16]. In [17], a significant reduction in lipid peroxidation and glutathione reductase activity is reported, while superoxide dismutase and catalase activities as well as proline contents are increased in pistachio seedling under varying saline regimes. It has generally been concluded that a large number of crops are sensitive to salt stress during the durations of seed germination and seedling establishment [18].

Cyanobacteria $(\mathrm{CB})$ are considered as a natural biofertilizer that play a fundamental role in soil maintenance and soil fertility buildup. It has been concluded that $\mathrm{CB}$ increase plant performances [19, 20], and raise soil water holding capacity via $\mathrm{CB}$ jelly structure [21], and decrease the level of soil salinity [22]. In addition, Glutathione (GSH) is an antioxidant, a tripeptide ( $\alpha$-glutamyle cysteinylglycine) that has been detected in all compartments of plant cell. GSH is an essential thiol antioxidant as well as a scavenger of reactive electrophilic compounds [23]. It has a gamma peptide linkage between the cysteine group and the $-\mathrm{COOH}$ group of the side-chain of glutamate. It prevents ROS damages to important components of cells [24]. In plants, GSH is functioned in the ascorbate-glutathione cycle to maintain redox homeostasis in plant cells in response to oxidative stress. GSH is functioned in this cycle by dehydroascorbate reductase (DHAR) for regenerating the ascorbate that scavenges $\mathrm{H}_{2} \mathrm{O}_{2}$, and it is converted to the oxidized form (GSSG) that is, then, regenerated by GSH-reductase $[25,26]$.

Therefore, this work was carried out to evaluate the potential beneficial effects of CB, used as seed inoculation, in combination with GSH, used as foliar spray, on growth, pods and seed yields, the contents of osmoprotectants, antioxidants, and nutrients, as well as on the activity of some antioxidative enzymes of soybean (Glycine max L., cv. Giza 111) plants grown on a sand culture under salt stress $(150 \mathrm{mM} \mathrm{NaCl})$.

\section{Materials and Methods}

\section{Growth condition and experimental design}

A pot experiment was conducted (repeated three times) in a greenhouse at the Farm of the Fayoum University, south west Giza, Egypt during the summer season 2017. Soybean (Glycine max L., cv. Giza 111) seed were purchased from the Agriculture Research Center, Giza, Egypt and sown on the first of May. Seed were surface sterilized using $0.1 \% \mathrm{HgCl}_{2}$ for $60 \mathrm{sec}$, and then washed several times using sterilize-deionized water. Plastic pots $(50-\mathrm{cm}$ diameter, $40-\mathrm{cm}$ depth) were filled with equal amounts of sand that was previously washed several times with commercial acid to remove all ions, and then washed several times with distilled water to remove the acid. Each pot was received 6 seed, and then pots $(n=90)$ were arranged in a completely randomized design a greenhouse for growing plants (repeated 3 times). Sand soil $\mathrm{pH}$ was adjusted back to the control $\mathrm{pH}$ (6.0-6.2) with diluted $\mathrm{H}_{2} \mathrm{SO}_{4}$.

\section{Irrigation and treatments}

The Hoagland's nutrient solution (1/2-strength) [27] was supplied to all pots at $100 \%$ field capacity (FC) every 2 days up to 20 days, at which plants were thinned to three in each pot. At the fourth leaf stage (21 days after sowing; DAS), seedlings were supplemented with $\mathrm{NaCl}$ at a level of $150 \mathrm{mM}$ along with the nutrient solution. Seedlings were sprayed with deionized water (control) or $1 \mathrm{mM}$ GSH beginning at the same time in which they received the salt treatment. Spraying of GSH on the foliage of plants was conducted to run off, two times; 21 and 35 DAS. Tween-20 was added (few drops) to the solution as a wetting agent. Supplementation of plants with $\mathrm{NaCl}$ was stopped at 
60 DAS. The selection of the GSH concentration $(1 \mathrm{mM})$ and $\mathrm{NaCl}$ level $(150 \mathrm{mM})$ was based on a small scale preliminary study (data not shown). Where, $1 \mathrm{mM} \mathrm{GSH}$ generated the best response and $\mathrm{NaCl}$ at the concentration above $150 \mathrm{mM}$ was lethal.

\section{Collection of samples}

Sixty-day-old seedlings were randomly taken from each treatment for various growth, physiobiochemical and antioxidative defense systems determinations. At harvesting (120 DAS), pods on all plants of each treatment were collected to assess pods and seeds yields components. Samples were divided into 3 groups as follows: Group A was used for measuring growth parameters, yield and yield components, and nutrient contents. Group B was the plant shoot system and new leaves that were immediately weighed, frozen with liquid $\mathrm{N}$ and stored in a deep freezer at $-20{ }^{\circ} \mathrm{C}$ up to use for extraction and assaying leaf enzymatic protein and enzymatic antioxidants (superoxide dismutase; SOD, catalase: CAT, and guaiacol peroxidase; GPOX). And group C was new fresh leaves that were used for assessing photosynthetic pigments, photosnthetic efficiency, free proline content, total soluble sugars, ascorbic acid, glutathione, $\alpha$-tocopherol, relative water contant, eletrolyte leakage and membrane stability index.

\section{Measurements of growth characteristics, and yield and yield components}

Plant samples $(\mathrm{n}=3)$ were separated to measure shoot length $(\mathrm{cm})$, plant leaf number, plant leaf area $\left(\mathrm{dm}^{2}\right)$, and shoot dry weights $(\mathrm{g})$. Shoots were dried at $70{ }^{\circ} \mathrm{C}$ for $48 \mathrm{~h}$ or until the constant weight. At harvest, pods on all plants were collected from each treatment and plant pod number, 100 -seed weight $(\mathrm{g})$ and plant dry seed weight $(\mathrm{g})$, seed protein and seed oil contents were also assessed.

\section{Measurements of physio-biochemical attributes}

\section{Photosynthetic Pigments and Photosynthetic Efficiency}

Contents ( $\mathrm{mg} \mathrm{g}^{-1}$ fresh weight; FW) of chlorophylls and carotenoids were estimated using the method in [28]. The methods in [29,30] were used to assess photosynthetic efficiency using fully expanded mature leaves on corresponding plants that were conducted at the same time of two sunny days. Chlorophyll fluorescence was assessed measuring maximum quantum yield of PSII Fv/Fm (by a Handy Portable fluorometer, Hansatech Instruments Ltd, Kings Lynn, UK)) using the formulae; $\mathrm{Fv} / \mathrm{Fm}=(\mathrm{Fm}-\mathrm{F} 0) / \mathrm{Fm}$. In addition, performance index (PI) was calculated based on equal absorption (PIABS).

\section{Free Proline and Total Soluble Sugars (TSS) Contents}

Using the method in [31], proline content was extracted (using $10 \mathrm{ml}$ of $3 \%, \mathrm{v} / \mathrm{v}$, sulphosalicylic acid) and determined, using freshly prepared acid-ninhydrin solution, in toluene phases collected carefully by reading the absorbance at $520 \mathrm{~nm}$ against a standard proline curve.

Content of TSS was measured after extraction by $96 \%(\mathrm{v} / \mathrm{v})$ ethanol using the method in [32]. TSS content was determined in the ethanolic extract reacted with freshly-prepared anthrone reagent by reading the absorbance at $625 \mathrm{~nm}$ using a Bausch and Lomb-2000 Spectronic Spectrophotometer (Thermo Spectronic, Cambridge, UK).

\section{Determinations of membrane stability index (MSI), electrolyte leakage (EL), and relative water content $(R W C)$}

MSI (\%), EL (\%), and RWC (\%) were determined using the methods described in [33, 34] using the fully expanded corresponding leaves, and the following formula, respectively:

$\operatorname{MSI}(\%)=\left[1-\left(\mathrm{C}_{1} / \mathrm{C}_{2}\right)\right] \times 100$

$\operatorname{EL}(\%)=\left[\left(\mathrm{C}_{\mathrm{b}}-\mathrm{C}_{\mathrm{a}}\right) / \mathrm{C}_{\mathrm{c}}\right] \times 100$

$\mathrm{RWC}(\%)=[(\mathrm{FM}-\mathrm{DM}) /(\mathrm{TM}-\mathrm{DM})] \times 100$

\section{Determination of non-enzymatic antioxidants contents}

The methods detailed in $[35,36,37,38]$ were followed to assess the contents of ascorbic acid (AsA), glutathione (GSH), and $\alpha$-tocopherol ( $\alpha$-TOC). 
The AsA content was homogenized using fresh leaf sample in 5\% (w/v) TCA. The resulted supernatant was used to assess the AsA content in the reaction mixture $(10 \mathrm{mM} \mathrm{DTT}, 0.2 \mathrm{M}$ phosphate buffer ( $\mathrm{pH} 7.4$ ), $0.5 \% \mathrm{NEM}, 10 \% \mathrm{TCA}, 42 \% \mathrm{H}_{3} \mathrm{PO}_{4}, 4 \% 2,2^{\prime}$-dipyridyl and 3\% $\mathrm{FeCl}_{3}$ ).

The GSH content was extracted from fresh leaves in buffer solution ( $2 \%$ sulfosalicylic acid, $1 \mathrm{mM} \mathrm{Na2EDTA}$ and $0.15 \%$ AsA). The resulted supernatant was used to measure the GSH content by GSH assay kit (Sigma Chemical Co., USA).

The $\alpha$-TOC content was determined using R-TOC and standard solutions $(20-200 \mu \mathrm{g} / \mathrm{ml})$ prepared using stock solution $(50 \mathrm{mg} / 100 \mathrm{ml} \mathrm{n}$-hexane). Samples were prepared, saponified, sliced, dried, homogenized, and suspended using water in a conical flask (0.5-1 L). After adding AsA, saponification was done and water was then added to reach the ethanol/water ratio to 0.3 . Then, $n-$ hexane/ethyl acetate [9:1 $(3 \times 100 \mathrm{ml})]$ was added. The mixtures were extracted three times, and the organic phases were then combined, washed, and filtered. After filtration and evaporation to dryness, residues were dissolved in n-hexane (HPLC grade) and cool-stored (at $-20^{\circ} \mathrm{C}$ ). The $\alpha$-TOC was assessed using a HPLC system with a Waters Bondapak $\mathrm{C}_{18}$ reversephase column. Mobile phase (94 methanol: 6 water) was used at the flow rate of $1.5 \mathrm{ml} \mathrm{min} \mathrm{m}^{-1}$ and UV detector was set at $292 \mathrm{~nm}$.

\section{Assaying the activities of enzymes}

One $g$ of fresh leaves was used to extract the antioxidant enzymes. Filtration and homogenization in liquid $\mathrm{N}_{2}$ with phosphate buffer $(0.05 \mathrm{M}, \mathrm{pH} 7.0)$ that contained EDTA $(100 \mathrm{mM})$ and PVP $(1 \%)$ were conducted for the biomass at $4{ }^{\circ} \mathrm{C}$. The extraction buffer: leaf biomass $(\mathrm{v} / \mathrm{w})$ proportion was $2: 1$, respectively. Centrifugation $(15,000 \times \mathrm{g})$ was done for the homogenate at $4{ }^{\circ} \mathrm{C}$ for $10 \mathrm{~min}$. By using phosphate buffer, the obtained supernatant was dialyzed overnight. Enzyme activities were performed, and protein content was determined in the homogenate according to [39].

Activities of superoxide dismutase (SOD; EC.1.15.1.1), catalase (CAT; EC. 1.11.1.6), and guaiacol peroxidase (GPOX; EC.1.11.1.7)

The activity of SOD was assayed as described in the method in [40]. The enzyme ability to inhibit the photochemical reduction of nitroblue tetrazolium (NBT) indicates to the enzyme activity and the change in the absorbance was read at $560 \mathrm{~nm}$. Reaction mixture was consisted of phosphate buffer $(25 \mathrm{mM}$, pH 7.8), NBT $(65 \mu \mathrm{M})$, riboflavin $(2 \mu \mathrm{M})$, TEMED, and the enzyme extract. This reaction mixture was exposed to light $\left(350 \mu \mathrm{mol} \mathrm{m} \mathrm{m}^{-2} \mathrm{~s}^{-1}\right)$ for $15 \mathrm{~min}$. The enzyme activity was expressed as nmol of $\mathrm{H}_{2} \mathrm{O}_{2} \mathrm{mg}^{-1}$ soluble protein $\mathrm{min}^{-1}$.

The CAT activity was assayed as described in the method in [41]. The decomposition rate of $\mathrm{H}_{2} \mathrm{O}_{2}$ read at $240 \mathrm{~nm}$ was recorded spectrophotometrically and calculated by using the molar extension coefficient by using $\varepsilon=45.2 \mathrm{mM}^{-1} \mathrm{~cm}^{-1}$. Reaction mixture was consisted of phosphate buffer, $\mathrm{H}_{2} \mathrm{O}_{2}(0.1 \mathrm{mM})$ and the enzyme extract. One unit of catalase activity was presumed as the amount of enzyme, which decomposed $1 \mathrm{nmol}$ of $\mathrm{H}_{2} \mathrm{O}_{2} \mathrm{mg}^{-1}$ soluble protein $\min ^{-1}$ at $30{ }^{\circ} \mathrm{C}$.

Guaiacol peroxidase activity was determined according to the method in [42].

\section{Leaf protein content}

A weight of $0.5 \mathrm{~g}$ fresh leaf tissue (FW) was homogenized using $3 \mathrm{ml}$ potassium phosphate buffer $(0.1 \mathrm{M})$ in a pre-chilled pestle and mortar. The homogenate was centrifuged $(15,000 \times \mathrm{g})$ for $20 \mathrm{~min}$. The resulted supernatant was used to assess the content of protein and the activities of antioxidant enzymes. Protein content was estimated as described in [39].

\section{Statistical analysis}

The obtained data were statistically analyzed, and the comparisons among all means of all treatments were perfected by using the procedure of Least Significant Differences (LSD) at $P \leq 0.05$ level as outlined in [43]. 


\section{Results}

Effect of cyanobacteria (CB) and glutathione (GSH) applications on growth characteristics of salt-stressed Glycine max L. plant

Data sited in Table 1 show the effect of CB seed inoculation and GSH foliar application $(1.0 \mathrm{mM})$ on growth characteristics of Glycine max L. plants grown under saline $(150 \mathrm{mM} \mathrm{NaCl})$ conditions. Data revealed that shoot length, No. of leaves plant ${ }^{-1}$, leaf area plant ${ }^{-1}$, and shoot dry weight were significantly decreased (from 52.4 to $30.5 \mathrm{~cm}, 24.5$ to 13.2 , from 11.8 to $6.2 \mathrm{dm}^{2}$, and from 8.94 to $4.23 \mathrm{~g}$, respectively) with salinity treatment compared to the control, while the decrease was improved (from 30.5 to 40.7 or $37.2 \mathrm{~cm}, 13.2$ to 20.8 or $17.8,6.2$ to 10.3 or $8.4 \mathrm{dm}^{2}$, and from 4.23 to 7.68 or $6.41 \mathrm{~g}$, respectively) with $\mathrm{CB}$ or $\mathrm{GSH}$ treatment under $\mathrm{NaCl}$ stress. However, the combined treatment of CB + GSH further improved shoot length (to $49.9 \mathrm{~cm}, 23.6$, $11.6 \mathrm{dm}^{2}$, and $8.79 \mathrm{~g}$, respectively) under salinity stress compared to the control.

Table 1. Effect of seed treatment with $\mathrm{CB}$ and foliar treatment with GSH $(1.0 \mathrm{mM})$ on growth characteristics of salt-stressed Glycine max L. plant

\begin{tabular}{lllll}
\hline \multirow{2}{*}{ Treatments } & Parameters & \multicolumn{3}{l}{} \\
\cline { 2 - 5 } & $\begin{array}{l}\text { Shoot length } \\
(\mathrm{cm})\end{array}$ & $\begin{array}{l}\text { Number of } \\
\text { leaves plant }\end{array}$ & $\begin{array}{l}\text { Leaf area } \\
\text { plant }^{-1}\left(\mathrm{dm}^{2}\right)\end{array}$ & $\begin{array}{l}\text { Shoot dry } \\
\text { weight }(\mathrm{g})\end{array}$ \\
\cline { 2 - 5 } Control & $52.4 \pm 4.2 \mathrm{a}$ & $24.5 \pm 2.6 \mathrm{a}$ & $11.8 \pm 1.9 \mathrm{a}$ & $8.94 \pm 0.96 \mathrm{a}$ \\
Salinity (S) & $30.5 \pm 3.1 \mathrm{~d}$ & $13.2 \pm 1.5 \mathrm{~d}$ & $6.2 \pm 1.2 \mathrm{~d}$ & $4.23 \pm 0.53 \mathrm{~d}$ \\
S+CB & $40.7 \pm 3.7 \mathrm{~b}$ & $20.8 \pm 2.4 \mathrm{~b}$ & $10.3 \pm 1.8 \mathrm{~b}$ & $7.68 \pm 0.83 \mathrm{~b}$ \\
S+GSH & $37.2 \pm 3.2 \mathrm{c}$ & $17.8 \pm 2.1 \mathrm{c}$ & $8.4 \pm 1.4 \mathrm{c}$ & $6.41 \pm 0.68 \mathrm{c}$ \\
S+CB+GSH & $49.9 \pm 4.1 \mathrm{a}$ & $23.6 \pm 2.8 \mathrm{a}$ & $11.6 \pm 2.0 \mathrm{a}$ & $8.79 \pm 0.92 \mathrm{a}$ \\
\hline
\end{tabular}

Values are means of 5 readings. Means in each column followed by different letters are different significantly at $p \leq$ 0.05 performed by Duncan's Multiple Range Test.

\section{Effect of cyanobacteria (CB) and glutathione (GSH) applications on pod and seed yields of salt-stressed Glycine max L. plant}

Data presented in Table 2 show that effect of CB seed inoculation and GSH foliar application $(1.0 \mathrm{mM})$ on pod and seed yields of Glycine $\max \mathrm{L}$. plants grown under saline $(150 \mathrm{mM} \mathrm{NaCl})$ conditions. Data revealed that pod number plant ${ }^{-1}$ was decreased (from 10.6 to 6.4) under salt stress compared to control, while its decrease was improved (from 6.4 to 8.0 or 7.1, respectively) with CB or GSH treatment. However, this parameter was further increased (to 10.2) with the combined CB + GSH treatment. For 100-seed weight parameter, it was reduced (from 10.7 to $5.9 \mathrm{~g}$ ) under salt stress treatment compared to control, but its reduction was improved (from 5.9 to 8.4 or $8.0 \mathrm{~g}$, respectively) with $\mathrm{CB}$ or GSH treatment, and further improved (to $10.4 \mathrm{~g}$ ) with the combined $\mathrm{CB}+$ GSH treatment. In similar, dry seed weight plant ${ }^{-1}$ character was decreased (from 10.0 to $5.4 \mathrm{~g}$ ) with $\mathrm{NaCl}$ salt treatment compared with control. However, its decrease was improved (from 5.4 to 8.1 or $7.3 \mathrm{~g}$, respectively), and was further increased (to $9.7 \mathrm{~g}$ ) with the combined treatment of CB + GSH compared to control. For seed protein content, it was decreased (from 31.2 to $23.8 \%$ ) under salt stress compared to control, but its reduction was improved (from $23.8 \%$ to 25.9 or $24.4 \%$, respectively) with $\mathrm{CB}$ or GSH treatment, and was further improved (to $30.8 \%$ ) with the combined $\mathrm{CB}+\mathrm{GSH}$ treatment compared to control. For seed oil content, it was reduced (from 21.6 to $15.3 \%$ ) under salinity stress compared to the control, but the decrease was improved (from $15.3 \%$ to 18.8 or $16.9 \%$, respectively) with the treatment of $\mathrm{CB}$ or GSH. The combined treatment of $\mathrm{CB}+$ GSH further improved this parameter (to $21.5 \%$ ) compared to control. 
Table 2. Effect of seed treatment with CB and foliar treatment with GSH (1.0 mM) on pod and seed yields of salt-stressed Glycine max L. plant

\begin{tabular}{|c|c|c|c|c|c|}
\hline \multirow[b]{2}{*}{ Treatments } & \multicolumn{5}{|l|}{ Parameters } \\
\hline & $\begin{array}{l}\text { Pods No. } \\
\text { plant }^{-1}\end{array}$ & $\begin{array}{l}\text { 100-seed } \\
\text { weight }(\mathrm{g})\end{array}$ & $\begin{array}{l}\text { Dry seed weight } \\
\text { plant }^{-1}(\mathrm{~g})\end{array}$ & $\begin{array}{l}\text { Seed } \\
\text { protein }(\%)\end{array}$ & $\begin{array}{l}\text { Seed oil } \\
(\%)\end{array}$ \\
\hline Control & $10.6 \pm 1.9 \mathrm{a}$ & $10.7 \pm 1.4 \mathrm{a}$ & $10.0 \pm 1.2 \mathrm{a}$ & $31.2 \pm 1.5 \mathrm{a}$ & $21.6 \pm 1.3 \mathrm{a}$ \\
\hline Salinity (S) & $6.4 \pm 0.8 \mathrm{~d}$ & $5.9 \pm 1.0 \mathrm{c}$ & $5.4 \pm 0.6 \mathrm{~d}$ & $23.8 \pm 1.2 \mathrm{c}$ & $15.3 \pm 1.0 \mathrm{~d}$ \\
\hline $\mathrm{S}+\mathrm{CB}$ & $8.0 \pm 1.4 b$ & $8.4 \pm 1.2 b$ & $8.1 \pm 0.9 b$ & $25.9 \pm 1.3 b$ & $18.8 \pm 1.2 b$ \\
\hline $\mathrm{S}+\mathrm{GSH}$ & $7.1 \pm 1.2 \mathrm{c}$ & $8.0 \pm 1.2 b$ & $7.3 \pm 0.8 \mathrm{c}$ & $24.4 \pm 1.3 b c$ & $16.9 \pm 1.1 \mathrm{c}$ \\
\hline $\mathrm{S}+\mathrm{CB}+\mathrm{GSH}$ & $10.2 \pm 1.7 \mathrm{a}$ & $10.4 \pm 1.3 \mathrm{a}$ & $9.7 \pm 1.1 \mathrm{a}$ & $30.8 \pm 1.4 \mathrm{a}$ & $21.5 \pm 1.4 \mathrm{a}$ \\
\hline
\end{tabular}

Values are means of 5 readings. Means in each column followed by different letters are different significantly at $p \leq$ 0.05 performed by Duncan's Multiple Range Test.

\section{Effect of cyanobacteria (CB) and glutathione (GSH) applications on leaf pigment contents and chlorophyll fluorescence of salt-stressed Glycine max L. plant}

Table 3 shows that total chlorophylls and carotenoids contents were decreased (from 2.12 to 0.90 and from 0.41 to 0.27 , respectively) with $\mathrm{NaCl}$ salinity $(150 \mathrm{mM})$ compared with control. However, their reductions were improved (from 0.90 to 1.58 or 1.30 , and from 0.27 to 0.31 or 0.27 , respectively) with $\mathrm{CB}$ or GSH treatment, and were further enhanced (to 2.05 and to 0.40 ) under the combined treatment of $\mathrm{CB}+\mathrm{GSH}$ compared to control. Also, Fv/Fm and PI were decreased (from 84.3 to 59.4, and from 73.7 to 52.3) with salt stress treatment compared to control, while their decrease were improved (from 59.4 to 74.5 or 67.7 , and 52.3 to 64.5 or 60.4 , respectively) with CB or GSH treatment, and were further increased (to 84.0 and to 73.0) with the combined treatment of CB + GSH compared with control.

Table 3. Effect of seed treatment with CB and foliar treatment with GSH $(1.0 \mathrm{mM})$ on leaf photosynthetic pigments ( $\mathrm{mg} \mathrm{g}^{-1}$ fresh weight) and chlorophyll fluorescence of salt-stressed Glycine $\max$ L. plant

\begin{tabular}{|c|c|c|c|c|}
\hline \multirow[b]{2}{*}{ Treatments } & \multicolumn{4}{|l|}{ Parameters } \\
\hline & $\begin{array}{l}\text { Total } \\
\text { chlorophylls }\end{array}$ & $\begin{array}{l}\text { Total } \\
\text { carotenoids }\end{array}$ & $\mathrm{Fv} / \mathrm{Fm}$ & PI \\
\hline Control & $2.12 \pm 0.08 \mathrm{a}$ & $0.41 \pm 0.03 \mathrm{a}$ & $84.3 \pm 1.8 \mathrm{a}$ & $73.7 \pm 1.9 \mathrm{a}$ \\
\hline Salinity (S) & $0.90 \pm 0.02 \mathrm{~d}$ & $0.27 \pm 0.01 \mathrm{c}$ & $59.4 \pm 1.2 \mathrm{~d}$ & $52.3 \pm 1.2 \mathrm{~d}$ \\
\hline $\mathrm{S}+\mathrm{CB}$ & $1.58 \pm 0.05 b$ & $0.31 \pm 0.02 b$ & $74.5 \pm 1.5 b$ & $64.5 \pm 1.6 b$ \\
\hline $\mathrm{S}+\mathrm{GSH}$ & $1.30 \pm 0.03 \mathrm{c}$ & $0.27 \pm 0.01 \mathrm{c}$ & $67.7 \pm 1.3 \mathrm{c}$ & $60.4 \pm 1.4 \mathrm{c}$ \\
\hline $\mathrm{S}+\mathrm{CB}+\mathrm{GSH}$ & $2.05 \pm 0.08 \mathrm{a}$ & $0.40 \pm 0.03 \mathrm{a}$ & $84.0 \pm 1.7 \mathrm{a}$ & $73.0 \pm 1.8 \mathrm{a}$ \\
\hline
\end{tabular}

Values are means of 5 readings. Means in each column followed by different letters are different significantly at $p \leq$ 0.05 performed by Duncan's Multiple Range Test.

Effect of cyanobacteria (CB) and glutathione (GSH) applications on relative water content (RWC), leakage of electrolytes (EL) and index of membrane stability (MSI) of leaves of saltstressed Glycine max L. plant

Data presented in Table 4 show that RWC (\%) and MSI (\%) were decreased (from 81.3 to $59.8 \%$, and from $76.0 \%$ to $51.2 \%$, respectively) with treatment of $\mathrm{NaCl}$ salinity $(150 \mathrm{mM})$ compared with control, while their decreases were improved (from 59.8\% to 74.2 or $67.7 \%$, and from $51.2 \%$ to 68.7 or $62.4 \%$, respectively) with CB or GSH treatment, and were further enhanced (to $81.4 \%$, and to $74.8 \%$, respectively) compared to the control. EL (\%) parameter was, in contrast, increased with salinity treatment, while it was decreased with CB or GSH treatment, and was further reduced with the combined $\mathrm{CB}+\mathrm{GSH}$ treatment compared to control. 
Table 4. Effect of seed treatment with $\mathrm{CB}$ and foliar treatment with GSH (1.0 mM) on leaf relative water content (RWC, \%), electrolyte leakage (EL, \%) and membrane stability index (MSI, \%) of salt-stressed Glycine max L. plant

\begin{tabular}{llll}
\hline \multirow{2}{*}{ Treatments } & Parameters & & \\
\cline { 2 - 4 } & RWC $(\%)$ & EL $(\%)$ & MSI (\%) \\
\cline { 2 - 4 } Control & $81.3 \pm 4.8 \mathrm{a}$ & $7.9 \pm 0.6 \mathrm{~d}$ & $76.0 \pm 6.3 \mathrm{a}$ \\
Salinity $(\mathrm{S})$ & $59.8 \pm 2.7 \mathrm{~d}$ & $15.8 \pm 0.9 \mathrm{a}$ & $51.2 \pm 4.6 \mathrm{~d}$ \\
S+CB & $74.2 \pm 3.9 \mathrm{~b}$ & $9.5 \pm 0.7 \mathrm{c}$ & $68.7 \pm 5.1 \mathrm{~b}$ \\
S+GSH & $67.7 \pm 3.5 \mathrm{c}$ & $11.2 \pm 0.8 \mathrm{~b}$ & $62.4 \pm 5.0 \mathrm{c}$ \\
S+CB+GSH & $81.4 \pm 4.5 \mathrm{a}$ & $8.0 \pm 0.6 \mathrm{~d}$ & $74.8 \pm 6.2 \mathrm{a}$ \\
\hline
\end{tabular}

Values are means of 5 readings. Means in each column followed by different letters are different significantly at $p \leq$ 0.05 performed by Duncan's Multiple Range Test.

Effect of cyanobacteria (CB) and glutathione (GSH) applications on contents of soluble sugars, proline, ascorbate (AsA), glutathione (GSH), and $\alpha$-tocopherol ( $\alpha$-TOC) of saltstressed Glycine max L. plant

Data in Table 5 show that leaf contents of total soluble sugars, free proline, AsA, GSH, and TOC of Glycine $\max$ L. plants were significantly decreased under the treatment of NaCl-salinity (150 mM) compared with control. While, the decreases in these parameters contents were significantly improved with CB or GSH treatment, and were further improved compared to control.

Table 5. Effect of seed treatment with $\mathrm{CB}$ and foliar treatment with GSH (1.0 mM) on leaf contents of total soluble sugars, free proline, AsA, GSH and $\alpha$-TOC of salt-stressed Glycine max L. plant

\begin{tabular}{llllll}
\hline \multirow{2}{*}{ Treatments } & Parameters & & & \\
\cline { 2 - 6 } & $\begin{array}{l}\text { Soluble sugars } \\
\left(\mathrm{mg} \mathrm{g}^{-1} \mathrm{DW}\right)\end{array}$ & $\begin{array}{l}\text { Free proline } \\
\left(\mu \mathrm{g} \mathrm{g}^{-1} \mathrm{DW}\right)\end{array}$ & $\begin{array}{l}\text { AsA }(\mu \mathrm{mol} \\
\left.\mathrm{g}^{-1} \mathrm{DW}\right)\end{array}$ & $\begin{array}{l}\text { GSH }(\mu \mathrm{mol} \\
\left.\mathrm{g}^{-1} \mathrm{DW}\right)\end{array}$ & $\begin{array}{l}\text { TOC }\left(\mu \mathrm{g} \mathrm{g}^{-1}\right. \\
\mathrm{DW})\end{array}$ \\
\cline { 2 - 6 } Control & $3.27 \pm 0.11 \mathrm{c}$ & $251 \pm 6 \mathrm{c}$ & $1.33 \pm 0.02 \mathrm{c}$ & $1.22 \pm 0.01 \mathrm{c}$ & $38.4 \pm 0.21 \mathrm{c}$ \\
Salinity (S) & $3.82 \pm 0.17 \mathrm{~b}$ & $333 \pm 8 \mathrm{~b}$ & $4.51 \pm 0.05 \mathrm{~b}$ & $3.21 \pm 0.04 \mathrm{~b}$ & $52.3 \pm 0.32 \mathrm{~b}$ \\
$\mathrm{~S}+\mathrm{CB}$ & $3.85 \pm 0.20 \mathrm{~b}$ & $330 \pm 7 \mathrm{~b}$ & $4.52 \pm 0.05 \mathrm{~b}$ & $3.36 \pm 0.04 \mathrm{~b}$ & $52.8 \pm 0.25 \mathrm{~b}$ \\
$\mathrm{~S}+\mathrm{GSH}$ & $3.87 \pm 0.17 \mathrm{~b}$ & $325 \pm 7 \mathrm{~b}$ & $6.52 \pm 0.06 \mathrm{a}$ & $5.88 \pm 0.06 \mathrm{a}$ & $64.4 \pm 0.36 \mathrm{a}$ \\
S+CB+GSH & $4.36 \pm 0.25 \mathrm{a}$ & $428 \pm 9 \mathrm{a}$ & $6.62 \pm 0.07 \mathrm{a}$ & $5.92 \pm 0.06 \mathrm{a}$ & $64.8 \pm 0.31 \mathrm{a}$ \\
\hline
\end{tabular}

Values are means of 5 readings. Means in each column followed by different letters are different significantly at $p \leq$ 0.05 performed by Duncan's Multiple Range Test.

Effect of cyanobacteria (CB) and glutathione (GSH) applications on content of enzymatic protein and enzyme activities of superoxide dismutase (SOD), catalase (CAT) and guaiacol peroxidase (GPOX) in salt-stressed Glycine max L. plant

Data presented in Table 6 show the effect of CB seed inoculation and GSH $(1 \mathrm{mM})$ foliar application on leaf content of enzymatic protein and leaf enzymatic activities of SOD, CAT and GPOX of Glycine max L. plants grown under saline conditions $(150 \mathrm{mM} \mathrm{NaCl})$. The activities of $\mathrm{SOD}, \mathrm{CAT}$, and GPOX were significantly increased with treatment of $\mathrm{NaCl}$ salinity compared with control, and these enzymes activities were further improved with CB or GSH treatment, and were excessive further improved with the combined $\mathrm{CB}+\mathrm{GSH}$ treatment compared to control. In contrast, leaf enzymatic protein content was decreased with salinity treatment, while it was improved with $\mathrm{CB}$ or GSH treatment, and was further increased with the combined $\mathrm{CB}+\mathrm{GSH}$ treatment compared to control. 
Table 6. Effect of seed treatment with $\mathrm{CB}$ and foliar treatment with GSH $(1.0 \mathrm{mM})$ on leaf enzymatic protein and the activities of enzymatic antioxidants (superoxide dismutase; SOD, catalase; CAT and guaiacol peroxidase; GPOX) of salt-stressed Glycine max L. plant

\begin{tabular}{|c|c|c|c|c|}
\hline \multirow[b]{2}{*}{ Treatments } & \multicolumn{4}{|l|}{ Parameters } \\
\hline & $\begin{array}{l}\text { Leaf protein } \\
\left(\mathrm{mmol} \mathrm{g}^{-1} \mathrm{FW}\right)\end{array}$ & $\begin{array}{l}\text { SOD }(\mu \mathrm{mol} \\
\left.\mathrm{mg}^{-1} \text { protein }\right)\end{array}$ & $\begin{array}{l}\text { CAT }(\mu \mathrm{mol} \\
\left.\mathrm{mg}^{-1} \text { protein }\right)\end{array}$ & $\begin{array}{l}\text { GPOX }(\mu \mathrm{mol} \\
\left.\mathrm{mg}^{-1} \text { protein }\right)\end{array}$ \\
\hline Control & $1.52 \pm 0.04 \mathrm{a}$ & $0.90 \pm 0.02 \mathrm{e}$ & $0.57 \pm 0.01 \mathrm{e}$ & $0.44 \pm 0.02 \mathrm{e}$ \\
\hline Salinity (S) & $0.84 \pm 0.02 \mathrm{~d}$ & $1.34 \pm 0.03 \mathrm{~d}$ & $0.85 \pm 0.02 \mathrm{~d}$ & $0.58 \pm 0.03 d$ \\
\hline $\mathrm{S}+\mathrm{CB}$ & $1.20 \pm 0.03 b$ & $1.83 \pm 0.04 b$ & $1.31 \pm 0.03 b$ & $0.79 \pm 0.04 \mathrm{~b}$ \\
\hline $\mathrm{S}+\mathrm{GSH}$ & $1.01 \pm 0.03 \mathrm{c}$ & $1.56 \pm 0.03 \mathrm{c}$ & $1.14 \pm 0.02 \mathrm{c}$ & $0.69 \pm 0.03 \mathrm{c}$ \\
\hline $\mathrm{S}+\mathrm{CB}+\mathrm{GSH}$ & $1.54 \pm 0.04 \mathrm{a}$ & $2.27 \pm 0.06 \mathrm{a}$ & $1.83 \pm 0.05 \mathrm{a}$ & $1.03 \pm 0.05 \mathrm{a}$ \\
\hline
\end{tabular}

Values are means of 5 readings. Means in each column followed by different letters are different significantly at $p \leq$ 0.05 performed by Duncan's Multiple Range Test.

Effect of cyanobacteria (CB) and glutathione (GSH) applications on lea macro-nutrients $(\mathrm{N}, \mathrm{P}, \mathrm{K}+$, and $\mathrm{Ca}+)$ and sodium $(\mathrm{Na}+)$ contents in salt-stressed Glycine max $\mathrm{L}$. plant

Data sited in Table 7 reveal the effect of CB seed inoculation and GSH (1 mM) foliar application on leaf contents of macro-nutrients $\left(\mathrm{N}, \mathrm{P}, \mathrm{K}^{+}\right.$and $\left.\mathrm{Ca}^{2+}\right)$ and sodium $\left(\mathrm{Na}^{+}\right)$of Glycine $\max \mathrm{L}$. plant grown under saline conditions $(150 \mathrm{mM} \mathrm{NaCl})$. Contents of $\mathrm{N}, \mathrm{P}, \mathrm{K}^{+}$and $\mathrm{Ca}^{2+}$ were significantly decreased with treatment of $\mathrm{NaCl}$ salinity compared with control, and these macronutrient contents were improved with $\mathrm{CB}$ or GSH treatment, and were further improved with the combined CB + GSH treatment compared to control. In contrast, leaf content of $\mathrm{Na}^{+}$was increased with salinity treatment, while it was significantly decreased with $\mathrm{CB}$ or GSH treatment, and was further decreased with the combined $\mathrm{CB}+\mathrm{GSH}$ treatment compared to control.

Table 7. Effect of seed treatment with $\mathrm{CB}$ and foliar treatment with $\mathrm{GSH}(1.0 \mathrm{mM})$ on the contents of macro-nutrients $\left(\mathrm{N}, \mathrm{P}, \mathrm{K}^{+}\right.$, and $\left.\mathrm{Ca}^{2+}\right)$ and sodium $\left(\mathrm{Na}^{+}\right)$of salt-stressed Glycine max L. plant

\begin{tabular}{|c|c|c|c|c|c|}
\hline \multirow{2}{*}{ Treatments } & \multicolumn{5}{|l|}{ Parameters } \\
\hline & $\mathrm{N}(\%)$ & $\mathrm{P}(\%)$ & $\mathrm{K}^{+}(\%)$ & $\mathrm{Ca}^{2+}(\%)$ & $\mathrm{Na}^{+}(\%)$ \\
\hline Control & $3.24 \pm 0.07 \mathrm{a}$ & $0.35 \pm 0.02 \mathrm{a}$ & $3.43 \pm 0.07 \mathrm{a}$ & $1.29 \pm 0.02 \mathrm{a}$ & $0.40 \pm 0.02 \mathrm{~d}$ \\
\hline Salinity (S) & $1.88 \pm 0.05 \mathrm{~d}$ & $0.21 \pm 0.01 d$ & $1.91 \pm 0.02 \mathrm{~d}$ & $0.87 \pm 0.01 \mathrm{~d}$ & $0.92 \pm 0.05 \mathrm{a}$ \\
\hline $\mathrm{S}+\mathrm{CB}$ & $2.66 \pm 0.06 \mathrm{~b}$ & $0.28 \pm 0.01 b$ & $2.68 \pm 0.05 b$ & $1.17 \pm 0.02 b$ & $0.56 \pm 0.03 c$ \\
\hline $\mathrm{S}+\mathrm{GSH}$ & $2.39 \pm 0.06 \mathrm{c}$ & $0.24 \pm 0.01 \mathrm{c}$ & $2.38 \pm 0.05 \mathrm{c}$ & $0.98 \pm 0.01 \mathrm{c}$ & $0.64 \pm 0.03 b$ \\
\hline $\mathrm{S}+\mathrm{CB}+\mathrm{GSH}$ & $3.21 \pm 0.07 \mathrm{a}$ & $0.34 \pm 0.02 \mathrm{a}$ & $3.38 \pm 0.08 \mathrm{a}$ & $1.25 \pm 0.02 \mathrm{a}$ & $0.41 \pm 0.02 \mathrm{~d}$ \\
\hline
\end{tabular}

Values are means of 5 readings. Means in each column followed by different letters are different significantly at $p \leq$ 0.05 performed by Duncan's Multiple Range Test.

\section{Discussion}

As awaited, soybean plants pretreated with a bio-fertilizer like cyanobacteria (CB) in integration with the antioxidant glutathione (GSH) foliar application conferred higher dry matter than stressed plants without treatments. The increased plant dry weight was obtained as a result of increase in other growth parameters, especially plant height, leaves number, and leaves area. This may also be attributed to the increase obtained of the efficiency of photosynthesis (measured in terms of leaf pigments; chlorophylls and carotenoids contents, as well as chlorophyll fluorescence; Fv/Fm and PI), which are supported by improved activities of (non-enzymatic and enzymatic) antioxidant defence systems by this integrative treatment (Tables 2-6). The beneficial effects of CB may be due to supplying plants by various nutrients, besides lowering soil $\mathrm{pH}$ that may facilitate soil nutrient availability for plants and their physiological processes like carbohydrate use and photosynthetic activity. Therefore, $\mathrm{CB}$ improve chemical characteristics of soil and enhance biological and physical characters that represent favourable factors for root development [44]. The report [45] showed that higher accumulation of salts in soil shows a lower water potential zone in soil. This makes the soil to be increasingly difficult for acquiring both water and nutrients by plants. 
Therefore, water deficiency (in terms of "physiological drought") is generated by salt stress. As considered as a key marker for studies of salt stress, relative water content (RWC) measurement is a generic method utilized to assess water balance in plant leaf during water deficient durations. RWC assesses the amount of water (\%) found in a leaf tissue as a hold fraction of the total volumetric water at cell full turgor. By maintaining cell RWC, permanence of metabolic activity is allowed by osmotic adjustments and other characters of adaptation to salt and/or drought stress [46]. Using different $\mathrm{CB}$ types significantly increased RWC, which may be attributed to accompany raise in hydraulic nature of branch root crosses that facilitate the radial water flow, and/or root morphology changes (i.e., root branching and its dry weight) [44]. Also, CB maintain stability of membrane structure (membrane stability index; MSI) under stress [20]. Cytoplasmic membranes of cells are an important one of the first objects of various unfavourable environmental factors. It has been, generally, accepted that cell membrane maintenance (for their integrity and stability) is one of the major targets for performing higher plant performance (acceptable growth and yields) [20]. Highest RWC and MSI, and lowest leakage of inorganic ions were observed with the integrative CB + GSH treatment compared to the individual treatments including the control (Table 4).

The beneficial impacts of the combined treatment of $\mathrm{CB}+\mathrm{GSH}$ could be elucidated on the basis of the improvement of soil physical, chemical and biological characters occurred by $\mathrm{CB}$, in addition to that GSH forms an important part of plant response to abiotic stress, including salinity [20]. It has been reported that GSH alleviates and repairs damages generated by reactive species of oxygen (ROS; $\mathrm{O}_{2}{ }^{-},{ }^{1} \mathrm{O}_{2}, \mathrm{H}_{2} \mathrm{O}_{2}$, and $\mathrm{OH}^{-}$). It, therefore, enables plants to adopt and/or develop a complex antioxidant defense system to effectively raise cellular defenses against oxidative stress induced by salt stress [47-49]. GSH application as an integrative treatment with CB conferred best results for soybean yield (Table 2) compared to the individual treatments including the control. This result attribute perhaps to the integrative roles of $\mathrm{CB}$ in repairing the rhizosphere; roots growth zone and GSH in alleviating and repairing the damages generated by ROS under salt stress [20].

It has been concluded that carotenoids are implicated in photosynthetic apparatus protection against photoinhibitory damages caused by ${ }^{1} \mathrm{O}_{2}$ that is producing by the excited triplet state of chlorophyll $[20,50]$. Carotenoids deactivate ${ }^{1} \mathrm{O}_{2}$ directly and quench the excited triplet state of chlorophyll, therefore, reducing ${ }^{1} \mathrm{O}_{2}$ formation indirectly. Closure of stomata due to osmotic stress or salt induced photosynthetic apparatus damage causes a reduction in chlorophylls content of mungbean leaves [45]. Plants pretreated with $\mathrm{CB}$ and then treated with GSH (an integrative treatment) conferred highest content of leaf photosynthetic pigments compared to other individual treatments (Table 3). CB can stimulate plant growth substances to improve leaf chlorophylls contents [51]. In this study, $\mathrm{CB}$ or $\mathrm{CB}+\mathrm{GSH}$ treatments increased total chlorophyll and carotenoid contents (Table 3). In CB, salt stress stimulates both respiration rate and PS1 activity, and also impairs the photosynthetic rate [52]. The overall performance index (PI) shows a single multiparametric expression, which combines all three steps of independent photosynthetic functions; the reaction centres density in the chlorophyll pool, trapped excitation energy, and its conversion to electron transport [53]. Values of PI and Fv/Fm (Table 3) indicate that photosynthetic performance due to $\mathrm{CB}$ or $\mathrm{CB}+\mathrm{GSH}$ significantly increased under salt stress. This indicates a positive effect of the bio-fertilizer $\mathrm{CB}$ on the plant photosynthetic machinery.

Accumulated contents of free proline, soluble sugars, GSH, AsA, and $\alpha$-TOC under salt stress preserve plant cells by balancing of osmotic strength of cytosol with that of vacuole and external environment [54]. In addition, free proline, as an important physiological index for plant response to salt stress, possesses a dual role in improving the tolerance to salt stress due to its ability to act in a similar way to the enzyme peroxidase and to scavenge ROS $[50,55]$. Application of CB increased the accumulation of proline in soybean plants (Table 5). Higher proline content is favourable to plants salt stress due to it participates in the leaf osmotic potential and, thus, in leaf osmotic adjustment [50]. In the current study, soluble sugar, AsA, and GSH contents were considerably increased with $\mathrm{CB}$. Accumulated content of organic solutes, especially soluble sugars (the main solutes) are involved in cell osmotic adjustment in glycophytic plants exposed to osmotic and salt stress [20]. Results herein showed that soybean plants with CB or CB + GSH led to a considerable increase in soluble sugars compared with control plants without CB or GSH. GSH participated in 
accumulation of soluble sugars that could be attributed to the protective role of GSH in photosynthetic systems and in salt tolerance by maintaining the redox status $[20,56]$. Moreover, accumulation of protein under salt stress could provide a storage $\mathrm{N}$ form, which is reused under excessive stress and may also play a positive role in osmotic adjustments [57]. Treatment with CB or $\mathrm{CB}+\mathrm{GSH}$ considerably increased protein content of soybean plants. $\mathrm{CB}$ cultures are capable of improving plant growth and increasing extracellular proteins (in the range of 32-82 $\mu \mathrm{g} \mathrm{ml}^{-1}$ ) and amino acids array [58].

Salt stress causes oxidative damages in plant tissues by stimulating ROS overproduction. The $\mathrm{O}_{2}{ }^{--}$produced due to stress in plant tissues is transformed by the enzyme SOD to $\mathrm{H}_{2} \mathrm{O}_{2}$ (a powerful oxidant) [59], which is prevented by ascorbate-glutathione cycle. This due to that SOD activity increases linearly with prolonged stress conditions, which in turn is attributed to that SOD is responsible for declining the oxidative stress-derived ROS. The enzyme CAT plays a crucial role in eliminating the oxidative stress-derived ROS like $\mathrm{H}_{2} \mathrm{O}_{2}$ by converting it to $\mathrm{O}_{2}$ and $\mathrm{H}_{2} \mathrm{O}$ [60]. In this study, using CB or CB + GSH resulted in an increase of CAT activity under a salty medium. It has been reported in [20] that $\mathrm{CB}$ or $\mathrm{CB}+\mathrm{GSH}$ increased the levels of antioxidant substances and improved the activities of the antioxidant enzymes; SOD, CAT, and GPOX in common bean plants under salt stress. It has been indicated in [61] that there are a number of mechanisms developed by $\mathrm{CB}$ that defend against stress, including production of photo-protective compounds like mycosporine-like amino acids (MAAs) and scytonemin, enzymes like SOD, CAT and GPOX, repairing of DNA damage, and synthesizing shock proteins.

Salt stress causes disruption in ionic equilibrium like $\mathrm{Na}^{+}$influx that causes dissipation of membrane potential and facilitates $\mathrm{Cl}^{-}$uptake down the chemical gradient. $\mathrm{Na}^{+}$ion is toxic to cell metabolism and has a dangerous influence on some enzymes functioning. High $\mathrm{Na}^{+}$ion level causes osmotic imbalance, disorganization of membranes, and inhibition of cell division and expansion. Further, high $\mathrm{Na}^{+}$ion level leads to a reduction in photosynthesis and ROS production [20, 45]. With $\mathrm{CB}$, it has been reported in [62] that accumulating the internal osmotica in inorganic ions form and preventing the intracellular $\mathrm{Na}^{+}$ion accumulation by reducing $\mathrm{Na}^{+}$influx, and by effective efflux mechanisms or metabolic adjustments have been in depth explained. $\mathrm{Na}^{+}$extrusion in $\mathrm{CB}$ is driven by the $\mathrm{Na}^{+} / \mathrm{H}^{+}$antiporter that is energized by improved activity of cytochrome oxidase. Inhibiting the $\mathrm{Na}^{+}$influx appears a major mechanism for $\mathrm{CB}$ survival against salt stress, and synthesis of salt-stress proteins is found out to occur in CB. As a result, CB cause an inhibition in the toxic $\mathrm{Na}^{+}$ion accumulation and ensure ionic equilibrium with increased contents of $\mathrm{N}, \mathrm{P}$, and $\mathrm{K}^{+}$[20], which are agreed with our results (Table 7). Therefore, there was a significant recovery in soybean growth at salt stress conditions. It has been reported in [14] that maintaining the ionic balance under salt stress is a prerequisite to protect plant against toxic ion build-up, with $\mathrm{K}^{+}$ accumulation and $\mathrm{Na}^{+}$at a minimum content in soybean leaves. The impact of $\mathrm{N}$ on plant growth and its development connects, often, with photosynthesis process [63]. Therefore, in this study, increased $\mathrm{N}$ accumulation with $\mathrm{CB}$ treatment improved growth and yield attributes. In [64], it has been reported that $\mathrm{CB}$ have the capability of fixing the atmospheric $\mathrm{Na}$ and possess some soil phosphate, solubilizing the insoluble phosphate by excreting organic acids, which solve the common problem of $\mathrm{P}$ chemical fixation in all soil types. These beneficial effects (indirect advantages for plants) of $\mathrm{CB}$ are supported by the other beneficial effects (direct advantages for plants) of GSH that deals effectively with ROS to increased plant tolerance to salt stress.

\section{Conclusions}

Pretreatment with CB bio-fertilizer to the environment possessed high salt stress appeared to be helpful to performance (growth, development, and yield) and the physio-biochemical processes of soybean plant. The integrative CB (for seed inoculation) + GSH (for plant foliar spray) treatment was most effective compared to using individual CB or GSH. This effective integrative treatment had improved levels of physio-biochemical attributes and antioxidant (non-enzymatic and enzymatic) defence systems and raised salt stress tolerance in soybean plants. Therefore, the integrative $\mathrm{CB}+\mathrm{GSH}$ treatment has been concluded to be a helpful strategy for improving growth and increasing yield of soybean plants when grown under salt-affected soils. 


\section{Conflict of Interest}

The authors declare that there is no conflict of interest.

\section{References}

[1] F. A. Kummerow, M. M. Mahfouz, Q. Zhou, Trans fatty acids in partially hydrogenated soybean oil inhibit prostacyclin release by endothelial cells in presence of high level of linoleic acid, Prostaglandins \& other Lipid Mediators, 84 (3-4) (2007) 138-153.

[2] S. Perveen, M. Shahbaz, M. Ashraf, Modulation in activities of antioxidant enzymes in salt stressed and non-stressed wheat (Triticum aestivum L.) plants raised from seed treated with triacontanol, Pak. J. Bot. 43(2011) 2463-2468.

[3] M. Shahbaz, M. Ashraf, F. Al-Qurainy, P. J. C. Harris, Salt tolerance in selected vegetables crops, Crit Rev. Plant Sci. 31(2012) 303-320.

[4] Z. Noreen, M. Ashraf, Assessment of variation in antioxidative defense system in salt treated pea (Pisum sativum L ) cultivars and its putative use as salinity toterance markers, J. Plant Physiol, 166 (2009) $1764-1774$.

[5] Z. Noreen, M. Ashraf, N. A. Akram, Salt-induced modulation in some key physiobiochemical processes and their use as selection criteria in potential vegetable crop pea (Pisum sativum L.), Crop Pasture Sci., 61(2010) 369378.

[6] M. M. Rady, G. F. Mohamed, Modulation of salt stress effects on the growth, physiochemical attributes and yields of Phaseolus vulgaris L. plants by the combined application of salicylic acid and Moringa oleifera leaf extract. Scientia Horticulturae, 193 (2015)105-113.

[7] M. M. Rady, E. M. Desoky, A. S Elrys, M. S. Boghdady, Can licorice root extract be used as an effective natural biostimulant for salt-stressed common bean plants? S. Afr. J. Bot. 121(2019a) 294-305.

[8] M. M. Rady, A. S. Elrys, M. F. Abo El-Maati, E. M. Desoky, Role of silicon and proline and their interplay in favor of increasing tolerance in Phaseolus vulgaris plants exposed to salt and cadmium toxicity, Ecotoxicol. Environ. Saf. (In Press), (2019b).

[9] M. M. Rady, A. Kuşvuran, A. H. F. lharby, Y. Alzahrani, S. Kuşvuran, Pretreatment with proline or an organic bio-stimulant induces salt tolerance in wheat plants by improving antioxidant redox state and enzymatic activities and reducing the oxidative stress. Journal of Plant Growth Regulation, OnLine First, https://doi.org/10.1007/s00344-018-9860-5, (2019c).

[10] M. Ashraf, M. Afzal, R. Ahmed, F. Mujeeb, A. Sarwar, L. Ali, Alleviation of detrimental effects of $\mathrm{NaCl}$ by silicon nutrition in salt-sensitive and salt-tolerant genotypes of sugarcane (Saccharum officinarum L.), Plant Soil. 326 (1-2) (2010) 1, 381-391.

[11] A. Saleem, M. Ashraf, N. A. Akram, Salt ( $\mathrm{NaCl})$ - induced modulation in some key physiobiochemical attributes in okra (Abelmoschus esculentus L.), J Agron Crop Sci. 197(2011) 202-213.

[12] S.Safi-naz, M.M.Rady, (2015) Moringa oleifera leaf extract improves growth, physiochemical attributes, antioxidant defence system and yields of salt-stressed Phaseolus vulgaris L. plants, Int J. ChemTech Res 8(11) (2015)120-134.

[13] N. A. Akram, M. Ashraf, F. Al-Qurainy, Aminolevulinic acid-induced changes in yield and seed-oil characteristics of sunflower (Helianthus annuus L.) plants under salt stress, Pak J Bot. 43 (2011) 2845-2852. 
[14] M. M Rady, B. Varma, S. M. Howladar, Common bean (Phaseolus vulgaris L.) seedlings overcome $\mathrm{NaCl}$ stress as a result of presoaking in Moringa oleifera leaf extract, Sci Hortic 162 (2013) 63-70.

[15] M. Ashraf, Biotechnological approach of improving plant salt tolerance using antioxidants as markers, Biotechnol Adv., 27(2009): 84 - 93.

[16] M. A Khan, Experimental assessment of salinity tolerance of Ceriops tagal seedling and sampling from the Indus delta, Pakistan Aquat. Bot., 70 (2001) 259-268.

[17] H. Abbaspour, Effect of salt stress on lipid peroxidation, antioxidative enzymes and proline accumulation in pistachio plants, J. Med Plants Res., 6 (2012) 526-539.

[18] J. Cuartero, M. C. Bolarin, M. J. Asins, V. Moreno, Increasing salt tolerance in the tomato, J. Exp. Bot., 57 (5) (2006) 1045-1058.

[19] T. Song, L. Martensson, T. Eriksson, W. Zheng, U. Rasmussen, Biodiversity and seasonal variation of the cyanobacterial assemblage in a rice paddy field in Fujian., China. The Federation of European Materials Societies Microbiology Ecology, 54 (2005) 131-140.

[20] M.M. Rady, S.S Taha, S. Kusvuran, Integrative application of cyanobacteria and antioxidants improves common bean performance under saline conditions, Sci. Hortic. 233(2018) 61-69.

[21] P. A. Rogar, P. A. Reynaud, Free-living Blue-green Algae in Tropical Soils, Martinus Nijh off publisher, La Hague, (1982).

[22] Saadatnia, Riahi, Cyanobacteria in pollution control, Journal of science Industrial research, 55 (2009) 685-692.

[23] R. Edwards, D. P. Dixon, V. Walbot, Plant glutathione S-transferases: enzymes with multiple functions in sickness and in health, Trends Plant Sci., 5 (2000)193-198.

[24] A. Pompella, A. Visvikis, A. Paolicchi, V. Tata, A. F. Casini, The changing faces of glutathione, a cellular protagonist, Bioch. Pharm. 66 (8) (2003) 1499-503.

[25] K. Asada, M. Takahashi, Production and scavenging of active oxygen in photosynthesis, In Photoinhibition. Edited by Kyle, D.J., Osmond, C.B. and Arntzen, C.J. Elsevier, Amsterdam, (1987) 227-287.

[26] G. Noctor, C. H. Foyer, Ascorbate and glutathione: keeping active oxygen under control, Annu. Rev. Plant Physiol. Plant Mol. Biol., 49 (1998) 249-279.

[27] D. Hoagland, D. I. Arnon, The water culture method for growing plants without soil. California Agricultural Experiment Station Bulletin. 347 (1983)1-39.

[28] D.I Arnon, Copper enzymes in isolated chloroplast Polyphenol-oxidase in Beta vulgaris L. Plant Physiol. 24 (1949)1-15.

[29] K. Maxwell G. N.Johnson, Chlorophyll fluorescence-a practical guide. J Exp Bot 51(345) (2000) 659-668.

[30] A. J. Clark, W. Landolt, J. B. Bucher, R. J. Strasser, Beech (Fagus sylvatica) response to ozone exposure assessed with a chlorophyll a fluorescence performance index, Environmental Pollution, 109 (2000) 501-507.

[31] L. S Bates, R. P. Waldeen, I. D. Teare, Rapid determination of free proline for water stress studies, Plant Soil, 39 (1973) 205-207. 
[32] J. J. Irigoyen, D. W. Emerich, M. Sanchez-Diaz, Water stress induced changes in the concentrations of proline and total soluble sugars in nodulated alfalfa (Medicago sativa) plants, Physiol. Plant, 8 (1992) 455-460.

[33] M. M. Rady, Effect of 24-epibrassinolide on growth yield, antioxidant system and cadmium content of bean (Phaseolus vulgaris L.) plants under salinity and cadmium stress, Sci. Hortic, 129 (2011) 232-237.

[34] A. Sh. Osman, M. M. Rady, Effect of humic acid as an additive to growing media to enhance the production of eggplant and tomato transplants. J. Hortic. Sci. Biotechnol, 89 (2014) 237244.

[35] K. Kampfenkel, M. Van Montagu, D. Inze, Extraction and determination of ascorbate and dehydroascorbate from plant tissue, Anal. Biochem., 225 (1995) 165-167.

[36] L. J. De Kok, F. M. Maas, J. Godeke, A. B. Haaksma, P. J. C. Kuiper, Glutathione, a tripeptide which may function as a temporary storage compound of excessive reduced sulphur in H2S fumigated spinach plants, Plant Soil, 91(1986) 349-352.

[37] E. J. M. Konings, H. H. S. Roomans, P. R. Beljaars, Liquid chromatographic determination of tocopherols and tocotrienols in margarine, infant foods, and vegetables, Journal of AOAC International, 79 (1996) 902-906.

[38] L. S. Ching, and S. Mohamed, Alpha-tocopherol content in 62 edible tropical pants, Journal of Agricultural and Food Chemistry, 49 (2001) 3101-3105.

[39] O. H. Lowry, N. J. Rosebrough, A. L. Farr, Protein measurement with the folin phenol reagent, J. Biol. Chem., 193(1) (1951) 265-275.

[40] Y. Kono, Generation of superoxide radical during autoxidation of hydroxylamine and an assay for superoxide dismutase, Arch. Biochem. Biophys, 186 (1) (1978) 189-195.

[41] H. Aebi, Catalase in vitro, Methods Enzymol, 105 (1984) 121-126.

[42] J. Putter, Peroxidase. In: Bergmeyer, H.U.(Ed.), Methods of Enzymatic Analysis, Verlag Chemie, Weinhan, (1974) 685-690.

[43] W. C. Snedecor, W. G. Cochran, Statistical Methods, $7^{\text {th }}$ ed. The Iowa State Univ. Press, Ames, Iowa, USA, Some key metabolites in some genetically diverse cultivars of radish (Raphanus sativus L.) Environ Exp. Bot. 67 (1980) 395 - 402.

[44] S. E. Khalil, A.S.A El-Noemani, Effect of bio-fertilizers on growth, yield, water relations, photosynthetic pigments and carbohydrates contents of Origanum vulgare L. plants grown under water stress conditions, Amer. J. Sustain. Agric., 9 (2015) 60-73.

[45] K. M Tawfik, Evaluating the use of rhizobacterin on cowpea plants grown under salt stress, Res. J. Agric. Biol. Sci. 4(1) (2008) 26-33.

[46] M. M Slabbert, G. H. J Krüger, Antioxidant enzyme activity, proline accumulation, leaf area and cell membrane stability in water stressed Amaranthus leaves, S. Afr. J. Bot. 95 (2014) $123-128$.

[47] N. Wutipraditkul, P. Wongwean, T. Buaboocha, Alleviation of salt-induced oxidative stress in rice seedlings by proline and/or glycinebetaine, Biol. Plant., 59 (3) (2015) 547-553.

[48] M. M. Rady, Kh. A Hemida, Sequenced application of ascorbate-proline-glutathione improves salt tolerance in maize seedlings, Ecotoxic. Environ. Saf., 133 (2016) 252-259. 
[49] M. M. Rady, R.S. Taha, A.H.A. Mahdi, Proline enhances growth, productivity and anatomy of two varieties of Lupinus termis L. grown under salt stress, S. Afr. J. Bot., 102 (2016) 221227.

[50] M. T. Abdelhamid, M. M. Rady, A. Sh. Osman, M. A Abdalla, Exogenous application of proline alleviates salt-induced oxidative stress in Phaseolus vulgaris L. Plants, J. Hortic. Sci. Biotechnol., 88 (2013) 439 - 446.

[51] V. Ordog, Beneficial effects of microalgae and cyanobacteria in plant/soil-systems, with special regard to their auxin-and cytokinin-like activity, In: International workshop and training course in microalgal biology and biotechnology, Mosonmagyarovar, (1999) 13-26.

[52] P. Sudhir, S. D. S. Murthy, Effects of salt stress on basic processes of photosynthesis, Photosynthetica, 42 (2) (2004), 481-486.

[53] M. A. Gururani, C. P. Upadhyaya, V. Baskar, J. Venkatesh, A. Nookaraju, S.W. Park, Plant growth-promoting rhizobacteria enhance abiotic stress tolerance in Solanum tuberosum through inducing changes in the expression of ROS-scavenging enzymes and improved photosynthetic performance, J. Plant Growth Regul., 32 (2) (2013) 245-258.

[54] H. Greenway, R. Munns, Mechanisms of salt tolerance in nonhalophytes, Ann. Rev. Plant Physiol., 31(1) (1980) 149-190.

[55] J. K. Zhu, Plant salt tolerance, Trends Plant Sci., 6 (2001) 66-71.

[56] N. Chaparzadeh, M. L. D'Amico, R. A. Khavari-Nejad, R. Izzo, F. Navari-Izzo, Antioxidative responses of Calendula officinalis under salinity conditions, Plant Physiol. Biochem., 42 (9) (2004), 695-701.

[57] M. P. J. C. Ashraf, P. J. C Harris, Potential biochemical indicators of salinity tolerance in plants, Plant Sci., 166 (1) (2004) 3-16.

[58] N. Karthikeyan, R. Prasanna, A. Sood, P. Jaiswal, S. Nayak, B. D. Kaushik, Physiological characterization and electron microscopic investigations of cyanobacteria associated with wheat rhizosphere. Folia Microbiol., 54 (2009) 43-51.

[59] V. Mittova, M. Tal, M. Volokita, M. Guy, Salt stress induces up-regulation of an efficient chloroplast antioxidant system in the salt-tolerant wild tomato species Lycopersicon pennellii but not in the cultivated species, Physiol. Plant, 115(3) (2002) 393-400.

[60] M. L. Dionisio-Sese, S. Tobita, Antioxidant responses of rice seedlings to salinity stress, Plant Sci. 135 (1) (1998) 1-9.

[61] S. C. Singh, R. P. Sinha, D. P Hader, Role of lipids and fatty acids in stress tolerance in cyanobacteria, Acta protozoologica, 41(4) (2002) 297-308.

[62] N. K. Singh, D.W. Dhar, Cyanobacterial reclamation of salt-affected soil, In: Genetic Engineering, Biofertilisation, Soil Quality and Organic Farming, (2010) 243-275. Springer Netherlands.

[63] V. Ivanova, A.Vassilev, Biometric and physiological characteristics of chrysanthemum (Chrysanthemum indicum L.) plants grown at different rates of nitrogen fertilization, J. Central Eur. Agric., 4 (1) (2003) 1-6.

[64] R. Sharma, M. K. Khokhar, R. L. Jat, S. K. Khandelwal, Role of algae and cyanobacteria in sustainable agriculture system, Wudpecker J. Agric. Res., 1(9) (2012) 381-388. 